\title{
Routines of Writing: Administration and the Poetics of Movement in Robert Walser's Works and the Film All This Can Happen
}

Simon Roloff, University of Hildesheim

\begin{abstract}
This article contextualizes Robert Walser's The Walk and All This Can Happen through Walser's literary practice and the social technologies of his time. It is argued that walking, perceiving, and writing in both works become part of a quasi-bureaucratic routine and therefore reflect certain historical changes in the office as an architectural and technical means of administration. Walser's earlier novel Jakob von Gunten is referred to in order to expand the argument and develop the final thesis that Walser's poetics of movement mirror an administrative control of "life" that was strongly shaped and remodelled around 1900.
\end{abstract}

Keywords: Robert Walser, body techniques (techniques du corps), biopolitics, poetics of knowledge

\section{Introduction}

This essay contextualizes The Walk and its interpretation in the film All This Can Happen through Walser's literary practice, which links perceiving, walking, and writing in a quasi-bureaucratic routine. Where the poetics and motives of The Walk and Walser's earlier novel Jakob von Gunten refer to this chain of operations in their portrayals of institutions, they reflect the historical changes leading to new techniques and practices of administration around 1900. Therefore Walser's poetics of movement make visible a biopolitical control of "life" that came into existence at his time.

\section{Writing as a Chain of Operations}

Robert Walser's The Walk is difficult to categorize as it defies expectations regarding plot, storytelling, or conventional form. In a stream of encounters, conversations, letters, descriptions, and uneventful stories without apparent thematic coherence, the narrator takes the reader on a rather random drift. Still, the text is anything but devoid of structure, it even seems to follow a preconceived concept whereby the narrator repeatedly stops to comment on his writing, to take a break from his work or to predict a future happening that he will describe later on. The Walk seems willfully 
composed as a chain of narrative vignettes that are the effects of disturbances and contingencies during writing. The formal peculiarities of Walser's text then appear to reflect the importance of the practices of literary representation. Siobhan Davies and David Hinton's All This Can Happen has taken this as a starting point for its own comment on the relationship of film as simulation. The work's collection of archive material connects the places, people, and stories of The Walk with the early history of the scientific study of motion in film. Again and again, the images are paused, halted, and recontextualized, giving way to new perceptual associations. Walser's highlighting of the process of writing is mirrored in the way filmic montage is foregrounded in the work, as a giving way to different means of reproducing the living world rather than just presenting it to the viewer.

In an intriguing passage of All This Can Happen, the narrator's visit to the municipal tax office is described in the voiceover to historical images of administrative buildings and clerks working inside. We see hands flipping through a card index, then in another frame a woman walking through an office, followed by a tripartite frame containing a walker and two motion studies by Edward Muybridge. Meanwhile, the narrator defends the necessity of talking a regular walk to his tax officer: "Walk I definitely must to maintain contact with the living world, without perceiving which I could not write one single word. [...] With the utmost love and attention, a man who walks studies every smallest living thing." ${ }^{11}$ Where the sonic and visual montage of All This Can Happen draws a connection between administrative procedures and the walking routine of the writer in Walser's text, it might be interesting to look at how much his poetics of describing life in nature writing, portraits, or biographies is based on the practices of an institution which also figures rather prominently in his work: the office, with its ways of recording, transcribing, and thus controlling society.

As a descendant from a poor, lower class family-his father's shop for writing equipment went bankrupt when he was still a child-Walser was forced to seek education as a bank-clerk in the 1880s. ${ }^{2}$ After that, he worked mostly short-term as a lower-tier employee, an accountant for banks and insurances, or as copyist for a lawyer. His first published writing originates from that time. After moving to Berlin, he mostly gave up working as an employee, and instead tried to make it as a full-time writer. However, he never ceased to obsessed with the routines of institutions. Be it in his diary of schoolboy Fritz Kochers Aufsätze, ${ }^{3}$ in his letters from the military, or in his well-known descriptions of the life of office clerks-the crucial role of imitation and repetition are always stressed when it comes to describing the transformative exertion of institutional power over the individual. And interestingly enough, a certain office routine appears to have persisted in Walser's self-discipline as a writer. ${ }^{4}$ In his Diary Fragment from $1926,{ }^{5}$ we find the description of a writing process that comes very close to what we know about Walser's own writing habits in his later years: the diarist tells us about how he is always planning his day ahead in order to write down a text 
which he thought about during his walks, just like the narrator of The Walk, who is struck by the idea of writing a text at the same time as wandering through the streets. Moreover, Walser's diarist from 1926 stresses the importance of a "routine" 6 of writing, in which life and literature are linked together and in which a text whose length he plans ahead will keep him busy for about twenty days, making it possible for him to capture life as a daily stream of small events. To represent life as it really is, we are told, is his sole aim in writing, and the ideal would be a text devoid of any phantasies or fictional distortions of stories and novels. In this mode of production, the diarist calls himself the "Bediente im Dienste des Schriftwesens," "servant in the service of writing," but the double-meaning of the German word schriftwesen is of significance here: on the one hand, it is an expression for official or judicial correspondence that has dropped out of use, and, at the same time, wesen is also being, a living entity. For Walser, the quasi-bureaucratic writing procedures, with a given text-length and alternating writing and walking hours, appear to turn scripture into a "writing-being." In this phase of Walser's writing, the text is not a fictional representation but a mimetic re-creation of the living world.

The idea of a carefully planned undertaking, an administrative technique and practice of writing to generate a text that comes as close as possible to life itself, is also crucial in what the narrator of The Walk says about the genesis of the narration:

Writers also, like generals, often make the most laborious preparations, before they dare march to the attack and give battle, or, in other words, fling their produce, or a book, into the book market [...]. I hope no estrangement will ensue, if I say that I am writing all these, (I trust pretty and delicate lines) with a quill from the Imperial High Court of Justice. Hence the brevity, pregnancy, and acumen of my language, at certain points well enough perceptible, at which now nobody need wonder anymore. ${ }^{8}$

In echoing the writing process of the Diary Fragment from 1926, this passage contains an accurate description of Walser's style in The Walk: The text might be a brief account, but the narrator's search for pregnancy often leads to intricate circuitousness that overstresses the minute details of small events. This seems to be one of the most particular features of Walser's prose; at the same time, one could perceive it as an artistic use of the formulas and idiosyncratic qualities of formal correspondence-its bureaucratic quality. Take, for example, the first sentence of The Walk, which describes the narrator's departure through constant circumvention and starts with what sounds like an official account or record of his actions: "I have to report that one fine morning, I do not know any more for sure what time it was, as the desire to take a walk came over me, I put my hat on my head, left my writing room, or room of phantoms, and ran down the stairs to hurry out into the street." ${ }^{\prime 9}$ The quasi-bureaucratic report frames the narration, setting the scene for The Walk. In a similar vein, the aforementioned 
dialogue in the tax office concludes with an overview of the following events by the narrator: the totality of what is written down, everything that happens in the text and in life, is thus recorded as if for official purposes.

At this point, we can say something about the poetics of life in Walser's literature: the perception and capture-the "study" of "every smallest living thing," ${ }^{10}$ which the narrator defines as the basic aim of the walker-does not only echo the intentions of our diarist but also very clearly resembles the poetic intentions of The Walk. Life, with Walser's stroller, is full of small and unimportant things, which are noteworthy because of their smallness, because of their uneventful and volatile nature. And this is recorded by a writing routine that links a certain form of data recording and the truthful recreation of impressions in daily literary office-work. Walser's poetics of small nonevents is made possible by an administratively inspired practice of writing, a misuse of bureaucratic protocols, or chains of operations, as an artistic practice.

We can trace this connection between a poetics of life and an office-routine-turnedliterary-strategy back to Walser's earlier work titled Jakob von Gunten, published in 1909. Here, we find the description of an administration controlling life, movement, and walking in a constant flow of institutional procedures like writing, guiding bodies, and modeling space. While showing how consistently Walser developed his poetics of life administration, I would also like to stress the wider historical context for this literature, in particular the rise of bureaucracy as one of the most dominant techniques of social control in the 20th century.

\section{A New Institutional Regime}

Judging from the title of its mysterious textbook What is the Aim of Benjamenta's School for Boys?, the institution in question in Jakob von Gunten was founded in a pedagogical spirit. But its initial ambitions seem to have waned significantly over time: "One learns very little here, there is a shortage of teachers, and none of us boys of the Benjamenta Institute will come to anything, that is to say, we shall all be something very small and subordinate later in life."11 There is only one class left when Jakob enters the program, held under the supervision of the principal's sister. From submitting to its ridicule and humiliating exercises, one can only expect "inward successes," ${ }^{12}$ as Jakob puts it, i.e. the boys will prosper only by developing a fatalistic attitude and cleansing themselves of any ambition other than to humbly serve and to acquire a dependent position in the world..$^{13}$

For all the varying perspectives that the Benjamenta Institute has offered to critics as an ironic re-enactment of the Turmgesellschaft in Goethe's Wilhelm Meisters Lehrjahre, ${ }^{14}$ a parody of the Lebensreform-Movement at the turn of the century, ${ }^{15}$ or even a modern monastery ${ }^{16}$ - the Institute has always been analyzed for its disciplinary approach in addressing its residents. ${ }^{17}$ Thus, one of its most prominent features has been overlooked. At one point, Jakob expresses his contentedness with the favorable 
impression made by his résumé and by a photograph he had to submit when entering the Institute, fueling his hope of acquiring a position as a servant. ${ }^{18}$ Driven by material plight and an insistent ambition, he repeatedly and unsuccessfully requests the principal to find him a job. ${ }^{19}$ As it seems, Jakob's biography and portrait are elements of an application that Mr. Benjamenta sends to possible employers. ${ }^{20}$ This means that the Benjamenta Institute-while in decline as a pedagogical institution-has taken up another line of business: it has become an employment agency. Jakob von Gunten describes a school that has become an institution, controlling and fueling a market economy rather than rather than offering the individual the prospect of a higher humanist education. The Benjamenta Institute does not teach writing as a form of educational training, but uses it as a form of social control, with the aim of administratively integrating individuals into a market economy. Its primary function in the school is the recording of data, i.e. of the life of the students. The protagonist, Jakob, engages in writing his CV for Mr. Benjamenta in order to be placed in one of the jobs the principal finds for everybody. But as Jakob keeps postponing the submission of his paper, this seems like a foreshadowing of the end of the novel where he is the only one to not leave the institution. His biography seems to be part of an enclosed institutional realm that characterizes life in a milieu of control according to Deleuze: "In the disciplinary societies one was always starting again (from school to the barracks, from the barracks to the factory), while in the societies of control one is never finished with anything."21

This end of discipline and the beginning of a new bureaucratic regime of control is also reflected in the infamous body exercises at the Institute, which are as means of what Deleuze terms "administering their last rites and of keeping people employed until the installation of the new forces knocking at the door." ${ }^{22}$ Accordingly, a class titled "How Should the Boy Behave?"- presumably originally designed according to the disciplinary approach-developed a subsequent performance routine and order with at least three qualities that deviate from the principles of prisons, schools, and physiological pedagogy. First of all, the tight exercise routine of the boys seems neither restricted to temporal nor spatial limits as they submit to the strange rules of principal's sister Mrs. Benjamenta not only during class. They remain in constant training even after the lesson is finished. From the moment when Jakob enters the program, each and every one of his actions are subject to scrutiny by the school management, including the way he eats, his choice of sleeping chambers, and his feelings towards his classmates. Everything seems to be significant, while at the same time the categories of every assessment remain obscure, known only to the siblings Benajamenta.

This appears to be related to what Jakob exclaims at the beginning of the novel: "God knows, sometimes my whole stay here seems like an incomprehensible dream." ${ }^{23}$ The discourse of dreams, rituals, and fairy tales in Jakob von Gunten, just like in Kafka's 
novels, points towards an institution of control that is centered around a constantly transforming, but ultimately empty center of power. Living under constant assessment with unclear outcome, Jakob develops a general attitude of anxious self-awareness that clearly shows in the passages of his diary where he gets carried away by his dreams and wishes and then corrects himself abruptly at the end of every entry. There is a certain bodily tension related to this technique of self-observation in which he and his classmates constantly live, a tension or alertness that is part of the institutional exercise of waiting for somebody or something. Part of the student's training is to wait for Ms. Benjamenta's arrival, standing still with eyes locked at the door before the official lesson starts. Also, during the long and boring hours of his free afternoons, during which he is not allowed to leave the Institute, Jakob conducts yoga-like exercises to keep himself awake and attentive. Waiting also seems to play a crucial part in the way authority is exerted by Mr. Benjamenta in his office: when entering the school, Jakob has to wait eagerly for any sign of reaction to his application by the principal. And it is one of Jakob's favorite pastimes to eavesdrop before the usually very quiet office. ${ }^{24}$ Therefore, even if their lessons appear on the surface to require discipline, the boys at the Benjamenta Institute are subject to a strangely seamless power that reigns through non-interaction or deflection. Its passive quality is best embodied by Mr. Benjamenta himself, who never shows up during the school lessons and remains idle in his office all day as Jakob ironically notes in his diary: "Such a Hercules cannot help falling asleep, that is, growling and musing as he reads his newspapers, when he confronts such a petty exercise as that of educating us." 25 Even though ironically tinted, this description of an educational strategy seems significant. Control in Mr. Benjamenta's institution not only has the tendency to exceed the classroom as the traditional arena of disciplinary instruction, but the headmaster also influences the boys through reflective withdrawal rather than direct confrontation. At first this might seem at odds with Ms. Benjamenta's strict teaching methods in the classroom. On a closer look though, the boys' uniform outward appearance-their equal facial expressions and their tiresome and repetitive training concerning the most mundane of activities, like opening a door or greeting someone-displays the effects of disciplinary control. ${ }^{26}$ But what we know about the actual procedures in Ms. Benjamenta's class is far from a regime of miniscule regulations or an extensive body of unbendable laws and orders. The rules to be followed by the pupils are not extensive at all: "One of the maxims of our school is: 'A little, but thoroughly,'" as Jakob reminds the reader, and: "To learn a little! The same thing over and over! Gradually I too am beginning to understand what a large world is hidden behind these words. To imprint something firmly, firmly on ones mind." 27 The best pupil in class will be the one who acts, based on the few rules and regulations which he has internalized, "so to speak, engraved in metal." ${ }^{28}$ Instead of directing the controling gaze to the appearance and behavior of the pupil, the institution in Jakob von Gunten aims at his interior. It does not govern by confrontational rules, but by shaping thoughts, motives, and attitudes. 
The administration in the Benjamenta institute is a ubiquitous power, ruling seamlessly by drawing on the inner motivations of the governed, engaging individuals in a constant training that is put into effect through writing. It has become a new, seamless way of governing life through a governmental-biopolitical institution. Instead of forcing life into the matrix of an ideal norm through disciplinary measures, the regime of writing in Walser's Jakob von Gunten controls individuals through flexible norms that are in constant transformation, as according to Michel Foucault. ${ }^{29}$ Walser's writing practices in the later stages of his work seem to mirror this flexible chaining of "life" as both an object of interest and of scrutiny, as do the institutions of his time with their bureaucratic routines.

\section{Administrative Poetics}

The protagonist Jakob takes regular walks in the city surrounding the Institute, describing small events and encounters in the tradition of Baudelaire's Tableaux Parisiens. ${ }^{30}$ The aesthetics of movement and writing in Jakob von Gunten are closely linked to The Walk and All This Can Happen. "Life" in Jakob von Gunten can be discovered and described from the enclosed realm of the Institute with its strangely undead residents, through moving, observing, and exercises of writing. According to Jakob, walking in the streets has an ameliorative effect on him. Watching everybody else being industrious makes him think of his own goals and makes him serve them better-just like in the Institute, where the ruling principles appear to persist only because of their ongoing performative embodiment in class. "The city educates, it cultivates, and by examples, what's more, not by arid precepts from books. There is nothing professorial about it, and that is flattering, for the towering gravity of knowledge discourages one. And then there is so much here, that fosters, sustains, and helps," writes Michel Foucault in Security, Territory, Population. ${ }^{31}$ The crowd in the street does not issue guidelines for the appearance and attitude of the individual but instead shapes everybody's behavior by example. It is a self-regulating entity that rules by "fostering" and "sustaining," not by curtailing the individual through idealized norms, bringing every moving body together in a shared space of vital interests and driving forces. The Benjamenta Institute, in its constricted architectural space, also fosters this kind of self-governed movement, and it is no accident that the boys are repeatedly referred to in the novel as a "crowd." ${ }^{32}$ Nor is it surprising when Jakob describes the classes as a perfect re-enactment of the streets outside the institute: "For me, our classes in dancing, propriety, and gymnastics, seem like public life itself, large, important, and then before my eyes the schoolroom is transformed into a splendid drawing room, into a street full of people." ${ }^{\prime 33}$ The biopolitical administration in the Benjamenta mimicks "life" through constant monitoring and exercising, and thus facilitates Jakob's entries in his diary, keeping him constantly alert and searching for small and unimportant details as well as humble in face of the common world in which he lives. 
The connection between a moving crowd in the street and a drawing made in a studio in Jakob's diary is interesting in this context. If the school serves as a perfect institutional mirror of the crowd in the streets, re-creating its self-governance without reference to law or written words, then the rules of the Institute also have to be enacted without a written justification. The rule-book What is the Aim of Benjamenta's School for Boys is still used in class, but to Jacob and his fellow comrades its guidelines remain as mysterious as anything going on during their training. Accordingly, the reader is almost never told about the actual content of the book, and the only way for Jacob to grasp the idea of his education is through a puzzling allegory which he thinks about when looking at the door that leads from one classroom into the initially mysterious and forbidden inner chambers of the Institute, home to the principal and his sister. Here he sees a helmet, a sheath, and a saber hanging on the wall as a rather mundane, or "tedious-looking" wall-decoration. Looking at the standardized kitsch, he can't help but think about the strange normative base for the institutional procedures to which he is subject: "This decoration is like a sign, or like a delicate evidence, of the rules that prevail here." ${ }^{34}$ This is an interesting observation by Jakob. If the rationale of the rules at the Institute is a sign and a "delicate evidence" at the same time, then essentially there is no justification for the rules but the effects they have on Jakob's body and those of his fellow comrades. The only way of exerting power over the individual in Jakob von Gunten is through an endless circle of performative selfvalidation. Thus, the institution in Walser's writing has been stripped bare of its idealistic goals and foundational principles. Chains of operations support and enable the existence of its power structure without any pre-existing law, they are the only rule to be observed by the pupils. As such, Walser's portrayal of the Benjamenta institute reminds the reader of the concept of techniques du corps discovered not long after him by the ethnologist Marcel Mauss on observing different ways of body training: according to Mauss' anthropological argument, we have to regard the human body as part of a chain of operations that links practices and technologies into one cultural continuum. ${ }^{35}$

Considering the discourse of law and order as an ornament in Jakob von Gunten, it is intriguing that around the time Walser wrote his novel in Berlin, the architecture of employment agencies began to develop into what we could call spatial ciphers of control. From 1902 onwards, there is evidence of a new kind of architectural approach to mass unemployment in the centralized job agencies of the time. Rather than incarcerating and disciplining the body of the unemployed (as was the case in the poorhouses and of welfare-institutions), the administration buildings of public unemployment insurances started to allow for crowds moving through their offices in great numbers. They featured a layout that was specifically designed to let the masses flow freely through the building, i.e. by preventing the risk of clustering in certain areas or using counters that were specifically built to prevent confrontation between staff and the unemployed. Many examples of early crowd control architecture 
followed after World War I, with the advent of public unemployment insurance in 1927. The buildings of the newly founded Reichsansalt for the unemployed-many of which were built by prominent members of the Bauhaus-school like Walter Gropiusfor example, used state of the art interior architecture to safeguard the daily service of these institutions: revolving doors, security counters, and construction plans ensured an even distribution of people through the buildings, while modular walls made it possible to react to quick changes in the economy and to a subsequent rise and fall of the demand for the agency's services. Working with little or no supervision through security teams, the architecture of the buildings adapted to what was known about the behavior of crowds. ${ }^{36}$ By establishing small chains of self-governed interaction between the bodies of the unemployed and the building, the unemployment agency of Walser's time and thereafter turned into biopolitical architectural milieus addressing the individual only as a particle of a moving crowd rather than as a perfectible body. This is precisely the strategy developed by the Benjamenta Institute and marks a new regime of controlling the individual as part of a mass. As Jakob puts it at one point: "The masses are the slaves of today, and the individual is the slave of the great mass idea." ${ }^{37}$

\section{Conclusion}

To conclude, Walser's particular poetics feature in the later stages of his works, starting with Jakob von Gunten, and later in The Walk and in the Diary-Fragment of 1926. These are linked to his portrayal of institutions and the way they exert power over the individual. In Walser's time, the administrative institutions began to transform themselves into entities that stood in close contact with the vital processes of the society they sought to regulate, and the institutional scenes of the former employee reflects this change as much as his poetics of movement. The open and flexible qualities of the biopolitical milieus of control and the practices of representation they developed are turned into an administrative poetics of recording life events in literature. The digressive style and the formal limitlessness that is characteristic for Walser's writing seem to be not only the effect of individual aesthetic decisions but also are a reflection of the broader cultural practices and coercive mechanisms of his time. With its extraordinary use of montage, All This Can Happen, rather then just audiovisually enhancing Walser's The Walk, stresses the dimension of the poetics analyzed here. In its own depiction of institutional power and movement, multiple frames stop cinematic movement on the one side and continue it on the other. Movements, gestures, and mimetic expressions from various sources become interrelated, echo each other, or answer one another. Hence, All This Can Happen is analyzing biopolitical institutions in accordance with Walser, through motifs and formal choices: administration from this perspective creates an artificial yet organic ornament, social coherence and necessity out of chaotic and contingent expressions of life. 


\section{Biography}

Simon Roloff is currently a junior professor for literary writing (creative writing) and literary studies at the University of Hildesheim. He studied philosophy, Kulturwissenschaften and Neue Detusche Literatur at Humboldt University Berlin and Creative Writing at the University of Leipzig. He wrote his doctoral thesis about Robert Walser at the faculty of media studies at the Bauhaus-University of Weimar and has been working as a Research Assistant and Postoctoral Fellow at Humboldt-University and the DFG graduate school Historiographies of Media.

Email: simon.roloff@uni-hildesheim.de

\section{Notes}

${ }^{1}$ Walser, The Walk, 85.

${ }^{2}$ Echte, Robert Walser, 45.

${ }^{3}$ Fritz Kocher's Essays is part of the 2013 collection A Schoolboy's Diary.

${ }^{4}$ See Walser, Fritz Kocher's Essays, and Kagen, The Wanderer as Soldier.

${ }^{5}$ Walser, Tagebuch-Fragment.

${ }^{6}$ Ibid., 59.

${ }^{7}$ Ibid., 59-60

${ }^{8}$ Walser, The Walk, 68-69.

9 lbid., 54.

${ }^{10}$ Wasler, The Walk, 85.

${ }^{11}$ Walser, Jakob von Gunten, 3.

12 lbid., 3.

${ }^{13}$ This has led many critics to believe that Walser is adding a dark twist to the motif of Bildung here, established in the German literature of Enlightenment. In works like Carl Philipp Moritz' Anton Reiser and Johann Wolfgang von Goethe's Wilhelm Meister, the modern individual with its desires and character traits is evolving over time through a series of interventions by well-meaning authorities which shape its character and guide it towards the realization of a Bildungsweg that, at the same time, is presented as the narrative structure of the novel. In opposition to this tradition of reading Walser, I would like to explain the institution in Jakob von Gunten through the contemporary restructuring of institutions in its time.

${ }^{14}$ Mayer, Bildungsroman, 210.

${ }^{15}$ Middleton, Introduction, xvii.

${ }^{16}$ Zimmermann, Der Babylonische Dolmetscher, 148. 
${ }^{17}$ With the exception of Hans H. Hiebel's Deleuzian reading of the novel in Zerstörung der Signifikanz, 242.

${ }_{18}^{18}$ Walser, Jakob von Gunten, 61.

19 Ibid., 64, 101, 137, 166.

${ }^{20}$ As such the Benjamenta Institute remains faithful to its inspirational counterpart, the actual servant school attended by Walser in the summer of 1905 . The latest biographical research into Walser's life has identified the school in question (Echte, Robert Walser, 180). A publication entitled Der Herrschaftliche Diener authored by the school's principal Mr. Manthei features a summary introduction to the duties and manners of the servant, reminiscent of what we know about the institutional training in Jakob von Gunten, followed by a brief description of the newly founded administrative department at the school, billed as the Herrschaftliche Dienerbüro, or Grand Bureau for Servants, which intends, both to support unemployed graduates financially and to refer them to vacant job opportunities. See: Manthei, Diener, S. 11

${ }^{21}$ Deleuze, Postscript, 3.

22 Ibid., 5.

${ }^{23}$ Walser, Jakob von Gunten, 6.

${ }^{24}$ Ibid., 8.

${ }^{25}$ Ibid., 15.

${ }^{26} \mathrm{Ibid} ., 57$.

${ }^{27}$ Ibid., 65.

${ }^{28}$ Ibid., 65.

${ }^{29}$ See Michel Foucault, Security, Territory, Population, 56.

${ }^{30}$ See Baudelaire, The Painter.

${ }^{31}$ Ibid., 46.

${ }^{32}$ Walser, Jakob von Gunten, 15, 36.

${ }^{33}$ Ibid., 117.

${ }^{34}$ Ibid., 34.

${ }^{35}$ See Mauss, Les Techniques du Corps. Recently the concept of "Kulturtechniken," or cultural techniques has referred to Mauss to describe chains of operations as the foundation of cultures by linking subjects, things or technologies and practices. Body techniques and technological structures stabilize and destabilize institutional power, regimes of discourse and modes of subjectication. For an introduction to the concept, see Bernhard Siegert, Cultural Techniques (2015).

${ }^{36}$ See also Roloff, Der Stellenlose.

${ }^{37}$ Walser, Jakob von Gunten, 69. 


\section{References}

Baudelaire, Charles. The Painter of Modern Life and Other Essays. Ed. Jonathan Mayne. London: Phaidon Press, 1995. 1-37.

Behrent, Michael C. "Accidents Happen: François Ewald, the 'Antirevolutionary' Foucault, and the Intellectual Politics of the French Welfare State." The Journal of Modern History, 82 (2010). 585-624. https://doi.org/10.1086/653042

Borchmeyer, Dieter. Dienst und Herrschaft: Ein Versuch über Robert Walser. Tübingen: Niemeyer, 1980.

Campe, Rüdiger. "Robert Walser's Institutionenroman Jakob von Gunten." Die Macht und das Imaginäre. Eds. Behrens, Rudolf and Jörg Steigerwald, 235-250. Würzburg: Königshausen \& Neumann, 2005.

Deleuze, Gilles. "Postscript on the Control Societies." October 59 (1992). 3-7. . Masochism: Coldness and Cruelty. New York: Zone Books, 1989.

Echte, Bernhard. Robert Walser. Sein Leben in Bildern und Texten, Frankfurt/M: Suhrkamp, 2008.

Ewald, François. L'État Providence [The Welfare State]. Paris: Gallimard, 1986.

Foucault, Michel. Security, Territory, Population: Lectures at the Collège de France 19771978. New York: Picador, 2009.

Hiebel, Hans H. "Robert Walser's Jakob von Gunten. Die Zerstörung der Signifikanz im Modernen Roman." Robert Walser. Ed. Klaus-Michael Hinz, 240-270. Frankfurt/M: Suhrkamp, 1991.

Kagen, Melissa B. "The Wanderer as Soldier: Robert Walser's Der Spaziergang Switzerland in World War I and Digression as Occupation." The German Quarterly 89 (1): 36-50.

Manthei, G. Der Herrschaftliche Diener. Berlin: Verlag der herrschaftlichen Dienerschule, 1911.

Roloff, Simon. Der Stellenlose. Robert Walsers Poetik des Sozialstaats. München: Wilhelm Fink 2015. 
Mayer, Gerhart. Der Deutsche Bildungsroman. Stuttgart: De Gruyter, 1992.

Middleton, Christopher. "Introduction." Jakob von Gunten. New York: NYRB Classics, 1999. v-xxii.

Seelig, Carl. Wanderungen mit Robert Walser. Frankfurt/M: Suhrkamp, 1977.

Siegert, Bernhard. "Door Logic, or, the Materiality of the Symbolic: From Cultural Techniques to Cybernetic Machines." Cultural Techniques: Grids, Filters, Doors and Other Articulations of the Real. New York: Fordham University Press, 2015.

https://doi.org/10.5422/fordham/9780823263752.003.0011

Walser, Robert. Geschwister Tanner, Frankfurt/M: Suhrkamp, 1986. . Jakob von Gunten. New York: NYRB Classics, 1999.

. "The Walk." Selected Stories. New York: Farrar Strauss \& Giroux, 2012. 54-104. . "Fritz Kocher's Essays." A Schoolboy's Diary, New York: NYRB Classics, 2013. 3-42. . “Das Tagebuch-Fragment von 1926." Zarte Zeilen, Frankfurt/M: Suhrkamp, 1999. 59-110.

Zimmermann, Hans-Dieter. Der Babylonische Dolmetscher, Frankfurt/M: Suhrkamp, 1985. 